\title{
The Dilemmas of Conducting Online Classes at Korean Language Training Courses in Indonesia during The Covid-19 Pandemic*
}

\author{
Suray Agung Nugroho \\ Fakultas Ilmu Budaya, Universitas Gadjah Mada \\ Korespondensi: suray@ugm.ac.id
}

Tim Pengabdian Masyarakat

Suray Agung Nugroho, Tri Mastoyo, Febriani Elfida Trihtarani

\begin{abstract}
This paper recounts the implementation of our department's community service to the teachers and owners of $L P K$ Bahasa Korea (private institutions teaching Korean language to prospective migrant workers). Based on our preliminary survey prior to conducting the community service, we learned that a lot of LPK were facing dilemmas in implementing online classes. They found it difficult to adjust themselves into online classes during the Covid-19 pandemic. Although some knew that running the LPK would mean the livelihood of their household, they even had to stop operating simply due to their lack of knowledge in conducting online classes. At this point, they needed assistance in making the best use of online platforms and in preparing online contents of Korean language teaching. Based on this, we designed a two-day community service fully implemented online which attracted as many as 55 enthusiastic participants from various LPK across Indonesia. During the program, participants learned from our experiences and from others about the endless possibilities of using free online platforms so as to maintain their LPK's livelihood and existence. Despite its limited time, participants managed to finally learn and choose the types of online platforms that suited their respective need. In particular, they also managed to learn practical ways in preparing Korean language-related online content to keep the enthusiasm and spirit of LPK students during and hopefully in the post-Covid19.
\end{abstract}

Keywords: LPK bahasa korea; korean language; online classes; online teaching platform

\begin{abstract}
Abstrak
Paper ini mengulik ulang pelaksanaan program Pengabdian kepada Masyarakat (PkM) yang dilakukan oleh Prodi Bahasa dan Kebudayaan Korea kepada para pengajar dan pemilik LPK (Lembaga Pendidikan dan Ketrampilan) Bahasa Korea. Berdasarkan hasil survei awal sebelum PkM dilaksanakan, diketahui banyaknya LPKyang menghadapi dilema dalam menerapkan kelas daring. Mereka kesulitan menyesuaikan lembaganya dengan kelas-kelas daring selama pandemi Covid-19. Bahkan beberapa LPK berhenti beroperasi karena kurangnya pengetahuan terkait dengan kelas daring, walaupun menjalankan LPK merupakan sumber penghasilan utama mereka. Pada titik itulah diketahui bahwa mereka memerlukan pendampingan untuk memanfaatkan platform pembelajaran daring yang tersedia serta untuk mempersiapkan konten-konten bahasa Korea secara daring. Berangkat dari keadaan inilah, Prodi Bahasa dan Kebudayaan Korea mendesain PkM 2
\end{abstract}

* This paper is based on the data gained from a community service conducted by Korean Language and Culture Department on July 2020. 
hari yang secara penuh diselenggarakan secara daring. PkM ini berhasil menarik minat 55 peserta dari berbagai LPK yang tersebar dari berbagai daerah di Indonesia Selama program berlangsung, para peserta belajar dari Prodi dan saling belajar dari peserta lain terkait dengan berbagai macam platform online yang bisa mereka gunakan serta belajar juga cara membuat berbagai konten bahasa Korea secara praktis demi keberlangsungan keberadaan LPK mereka. Terlepas dari pendeknya waktu, para peserta berhasil belajar dan akhirnya memilih platform online yang cocok dengan LPK masing-masing. Yang lebih penting lagi, mereka tahu cara mempersiapkan konten bahasa Korea yang praktis untuk mempertahankan semangat belajar para peserta kursus di LPK, baik selama masa pandemi maupun nanti pasca-Covid19.

Kata Kunci: LPK bahasa korea; bahasa korea; kelas online, platform pengajaran online

\section{Introduction}

Under the seemingly ever-changing policies related to Covid-19 prescribed by the Indonesian government, educational institutions across the country scrambled to change their teaching atmosphere and methods from in-class meetings into online ones during the pandemic. For institutions with ample resources in term of fund and IT-literate human resources, such abrupt change did not entirely disrupt the classes. However, for some educational institutions, especially the small and private ones, Covid-19 was a serious blow to the continuity of educational service to the students or even to their overall livelihood.

In light of this, during the first three months of social and travel restrictions (AprilJune 2020), there were two notable government policies that attracted our department's (Korean Language and Culture Program) concern. First, the policy from Ministry of Education ordering all schools and universities in all regions not to open or conduct face-to-face classes until 2021 or until further notice. ${ }^{1}$ With this issuing, educational institutions almost had no options but to adhere to the government policies. Second, the policy from Ministry of Manpower suspending all placement of migrant workers to recipient countries, including South Korea, until further notice. ${ }^{2}$ The latter policy also grabbed our attention because, to some extent, it concerned our department's cooperation partners outside campus, especially LPK Bahasa Korea. ${ }^{3}$ In other words, Covid-19 and its unprecedented impacts had prompted our curiosity and concern into the "livelihood" of LPK Bahasa Korea during the pandemics.

On paper, the policies can be regarded as a good thing in the sense that the government had swiftly managed to take actions responding to the situation. On the other hand, as an institution specializing in Korean language, we could not but notice

1 https:/www.kompas.com/edu/read/2020/06/15/180224171/mendikbud-nadiem-makarim429-kota-kabupen-di-indonesia-dilarang-membuka 'Minister of Education prohibits the re-opening of all educational institutions in 429 districts in Indonesia'

2 https://www.cnbcindonesia.com/news/20200320122952-4-146413/gegara-corona-mulaihari-ini-pengiriman-tki-dihentikan 'Due to Corona, as of today (March 20,2020), the placement of all migrant workers are to be suspended'

3 LPK Bahasa Korea (Lembaga Pendidikan \& Ketrampilan Bahasa Korea 'Korean Language Education Centers') are private language courses catering the need of prospective migrant-workers in learning Korean language prior to taking the Korean language proficiency test as one of the requirements to work in Korea. In this paper, we use the term "LPK" in a plural sense to denote and refer to those private language courses. 
the dilemmas experienced by the owners of LPK in coping with such policies. We had suspected that not all LPK would heed the government's order due to the fact that operating the LPK could be the only source of livelihood for some LPK owners. Not to mention the need of reliable internet access for the students scattered in different regions across the country.

As previously stated, in the midst of Covid-19 pandemic, the government, through the Ministry of Manpower Decree, temporarily suspended the placement of Indonesian migrant workers abroad. Of course, it was one of the efforts to protect all migrant workers and to prevent the spread of the Covid-19 outbreak, apart from the request of the recipient countries. Those are the basic rationales behind the issuing of the decree of the Minister of Manpower of Republic of Indonesia Number 151 of 2020 which highlighted the temporary suspension of any placement of Indonesian migrant workers abroad. Since it took effect on March 20, 2020, many prospective migrant workers became anxious and worried about their future. At this point, they concerned more about their shattered dream of working abroad, instead of worrying more about the on-going Covid-19 dangerous situation.

This was exactly what happened to prospective migrant students in Indonesia. For those who were in their final stage of placement, they could let out a relief since the government had guaranteed that they could proceed the process provided the receiving countries accept them. On the other hand, for those who were still in the early stages of preparing to be migrant workers, like those studying Korean language at LPK, they needed to recalculate their future plan. To make matter worse, the annual EPS TOPIK scheduled on April 2020 was postponed or suspended. ${ }^{4}$ At the same time, those already enrolled at LPK could not but stay at home studying online--if they ever indeed studying anything at all.

In the middle of this situation, LPK seemed to be facing dilemmas of having to maintain their existence as well as providing the much-needed Korean language classes for their students. In other words, no matter what happened, they knew that they needed to keep on teaching Korean language to the prospective migrant workers. However, the worsening Covid-19 situation and the governmental mandate of implementing online classes had to some extent hindered the smooth operation of the LPK. It is worthnoting that most students at LPK came from far away regions, not necessarily from the surrounding cities where LPK were located. The semi-lockdown as well as the limited social gathering had halted the classes. Despite the limited movement; however, many students had managed to return to their hometowns in early March once they heard that the classes were about to be conducted online for fear of not being able to go home.

In short, LPK were in limbo. Some adhered the government's order of conducting online classes while some stuck to their face-to-face meetings with reasons as stated earlier. It was, then, a highly important time for Korean Language and Culture Department, Universitas Gadjah Mada to deliberately act on this situation. Along with other colleagues, we took the initial steps to map out how our department could carry out a Community Service in the middle of the Covid-19 pandemic.

4 As of November 2020, later date were not yet visible or undecided. According to the official website of South Korean Human Resources Department in charge of the exam (http://eps.hrdkorea. or.kr), EPS-TOPIK was still suspended until further notice due the outbreak of Covid-19. 
As an educational institution with interest in learning $\&$ researching on Korean language and culture, we have maintained a close ties with LPK owners as well as Korean language teachers in various LPKs. This close ties were only made possible since we incorporated them into our previous community service programs. We have made them the partners of our department's community programs.

For this reason, in the midst of the Covid-19 pandemic situation, we came up with a community outreach that remained true to our department's goals. We set forth an idea of carrying out a community service project geared towards the LPK in need of assistance in managing the online classes---which for some LPK sound a bit far-reaching, if not probably out-of-reach. We wanted to share the knowledge and experiences related to the implementation of online classes which were likely to be needed by LPK even though the new normal policy had been enacted.

\section{Program Approach and Implementation}

\section{Preliminary Approach Prior to the Implementation of Community Service}

Since the quarantine order and limited social movement took effect, the only way for us to assess the situation was, of course, by online communication with LPK owners who mostly also happened to be the language instructors at their own institutions. To simplify what we needed to do in the first place, we contacted them via a WhatsApp group and asked their favor of filling out a short online survey on their responses to the proposed online classes by the government. We needed to conduct this preliminary survey in order for us to learn how they situated themselves in the on-going pandemic so as to enable us to map out their needs.

In short, we managed to ask them to fill out a short survey through a Google link. The questions were mainly related to Covid-19 situation and its impact on classes at their respective LPK. There were as many as 90 LPK filling out the survey. Many of them were the members of Pelbakori (Perkumpulan Lembaga Pelatihan Bahasa Korea Se-Indonesia 'Association of Korean Language Training Courses in Indonesia').

The survey taught us that when the Indonesian government advocated, promoted, and urged the implementation of online classes in almost all educational institutions in the midst of the Covid-19 pandemic, it turned out that there were still some $L P K$ in numerous regions conducting face-to-face classes.

Apakah di tengah situasi Covid-19 seperti ini, LPK Anda tetap mengadakan kelas secara tatap muka?

90 responses

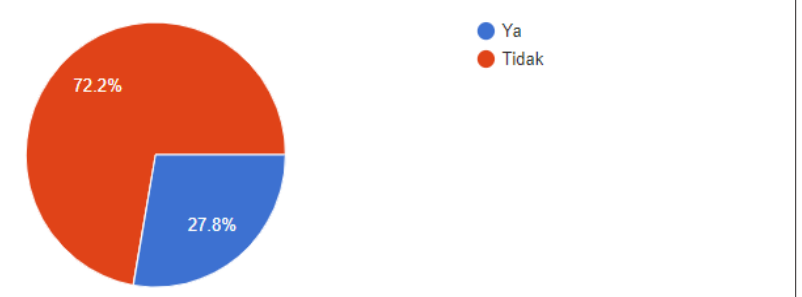

Pic. 1. Percentage of LPK conducting online or offline classes during the pandemic. (Source: Screenshot from Google Form survey) 
Despite the government's order to prioritize online classes, some LPK still managed to hold face-to-face classes (27.8\%) in the midst of Covid-19 pandemic. The reasons as to why they kept doing it was indeed vary: (1) course participants preferred face to face learning rather than online classes; (2) face-to-face classes were deemed clearer, easier to understand, effective, and thus maximizing the students' abilities; (3) participants still had to prepare for the EPS TOPIK (Employment Permit System - Test of Proficiency in Korean) which could be held at any time by the Korean government; (4) the LPK and the participants lived in the green zone areas considered free of any reported cases of Covid-19; (5) the Indonesian government had begun implementing a new normal policy so that some LPK dared themselves to start face-to-face classes starting on June 8, 2020; (6) the local district Manpower Office had given permission for them to conduct on-site classes provided health protocols were met, such as allowing a maximum of 10 students per class; (7) some LPK and their students were not yet familiar with or barely knew how to initiate online classes; and finally, (8) the intermittently slow internet network hindered their online classes.

Those participants took an active role in succeeding this community service. By being active, as previously mentioned, they even willingly participated in a brief survey that preceded the community service program. This survey had succeeded in mapping the situation and conditions of several LPK within Pelbakori network. Based on the findings on the early survey, we learned many other facts otherwise overlooked. And, these only strengthened our belief that this community service was indeed relevant to the situation occurring in our society.

First, the survey indicated that some LPK were already conducting online classes with the following reasons: (1) apart from realizing that face-to-face classes were being prohibited by the government, LPK were also concerned about the transmission of Covid-19 which could affect the health of the participants and the teachers; (2) some considered that online classes were easier and that they still needed income; (3) a number of participants came from distant regions and thus impossible for them to come directly to LPK in the middle of the pandemic; (4) some LPK believed that their students must be safe while learning the modules even from home; (5) some LPK thought that many participants must keep on practicing on the EPS-TOPIK exam questions even from home; and (6) some realized that online classes enabled them to embrace participants from outside the region at a lower cost. In short, the survey showed that $73 \%$ of LPK were using online platforms during this pandemic.

Second, the survey uncovered the fact about some LPK were on total holiday with practically no activities which in turned had impacted their revenue and earnings. In other words, they had not held any face-to-face and online classes since March 2020. There were 17 LPK stating that they were basically inactive. One even mentioned being unable to pay the electricity unless they cut down other expenses.

Seeing this fact, it was evident that Covid-19 had forced the education world to temporarily shift their learning platform into the online learning system. However, as later found out, there were still some LPK who regarded online classes as nothing more than just a passing alternative which would soon be abandoned when things return to normal or when this pandemic ended. For this reason, this community service program were targeted towards those who needed to change their perspective on online classes. 
At the same time, we did not want to force or pressure or put the wrong idea that online classes were better off than face-to-face ones. We simply wanted to assert the fact that in times of unpredictability, online learning could be used as an effective method that actually enhanced learning environment even when the situation was back to normal.

We realized that what we had done might not be warmly welcome by all LPK since they might have had their own capabilities and resources to conduct online classes. However, through this community service, we asked the owners and teachers at LPK to at least expand their perception and understanding about the wide varieties and choices of using technology in learning the language. After all, we also used this opportunity to maintain and to upgrade the capability of both the owners and teachers in (re)packaging Korean language learning system in their respective LPK. The Covid-19 situation needed to be seen as a momentum and a stronghold to broaden their horizon of the importance of learning Korean language in their respective LPK.

Third, the survey also unraveled the fact that some LPK which, despite organizing online classes, simply sent out homework and questions through the WhatsApp group and the instructors simply provided the answer keys.

In this case, there were still some LPK who did not know at all how to make the most of long-distance class technology (13\%). Zoom being the most popular one and WhatsApp came second, followed by Google forms and drive for file sharing, and then Webex. From the same questionnaire, it is found that others felt that internet data and costs were their main obstacles (14\%). There were those who felt that they did not have the resources to do it (19\%). In addition, there was a sense of boredom felt by the students at LPK since online classes began.

The results of this survey had pushed and convinced us that the community service we did could become an important boost for LPK's livelihood. At least, we could assist them in (re)packaging Korean learning contents to be fun and interesting for participants as well as teachers even though they were done online during and post Covid-19.
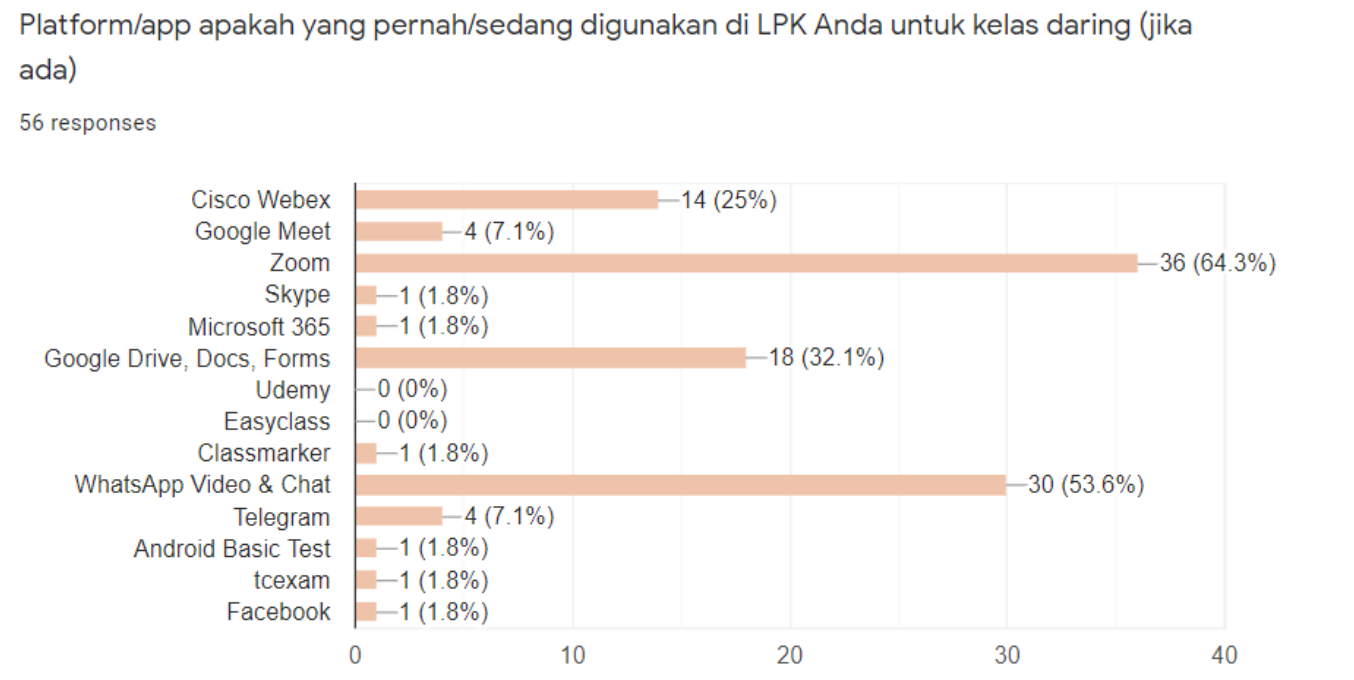

Pic. 2. Types of online platforms used by LPK. (Source: a screenshot of Google Form survey) 
Despite our fear of lukewarm welcome, 93\% said that they wanted to take part in our community service because they wanted to learn other methods of (re)packaging Korean language through online classes. In order to make sure that this community service met its goals, we had designed a 5-hour long online class carried out in a twoday online meeting via Cisco Webex Meeting.

\section{The 2-Day Community Service}

In terms of the participants, there were initially 90 representatives ${ }^{5}$ from various LPK that registered themselves into our database. They come from LPK across various regions in Java, Sumatra, West Nusa Tenggara, and Sulawesi. For the sake of maintaining a good record for this research, there were LPK from cities of Banjarnegara, Bekasi, Brebes, Kebumen, Karanganyar, Jepara, Malang, Majalengka, Salatiga, Sukoharjo, Surabaya, Temanggung, and Wonosobo (1 participant each). Then, there were those from Banyumas, Indramayu, Jember, Pati, Sragen, and Yogya (2 participants each); those from Purwokerto, Semarang, Kendal, Magelang, Kediri, Tulungagung, and Cirebon (3 participants each). Followed by Grobogan and Ponorogo (5 participants each). Meanwhile, the city of Cilacap held the record (16 representatives from 16 different LPK). Last but not least, participants coming from outside Java were those from Bengkulu (2 participants) and Palembang, Bone, \& Praya-Lombok (1 participant each).

It is worth-noting that by involving LPK owners and Korean language teachers from diverse LPK across the country, we embraced one of the vital actors in the field of Korean language teaching at the grass-root level in Indonesia: LPK Bahasa Korea. They were probably the first option that prospective migrant workers came to think of where they might want to learn Korean language. For this reason, the participants of our community service were the real actors whose work contributed to the issue of migration in Indonesia. In other words, the owners and teachers at LPK Bahasa Korea were the members of the community that directly assisted the country in changing the lives of thousands who otherwise might still be an underprivileged part of the society. In addition, these LPK have provided a learning environment by opening a place for prospective migrant workers to learn Korean language prior to their departure to Korea. And, that is how we understood the importance of LPK's existence and how we found it necessary for them to actively engage themselves in this community service.

Thus, on the first day, held on July 9, 2020 from 09.00 until 12.00, it was a relieving moment that we did witness the enthusiasm and eagerness of the participants to learn something out of this community service. Similarly, on the second day, held a week later on July 16, 2020, we also witnessed the same excitement of the participants. A one-week interval was deliberately designed so as to give all participants enough time to internalize what they learned in the first week and to have them make their own online-teaching content to be shared with the whole participants in the following week.

The recount what happened, the first day was initiated with a ceremonial event to kick off the first online community service we ever had. Our team set up the Webex platform earlier on that day and we already saw some participants joined the Webex

5 However, prior to the implementation, there were some who decided to cancel their participation due to their overlapping schedules. On the day of the community service, there were 55 registered participants. 


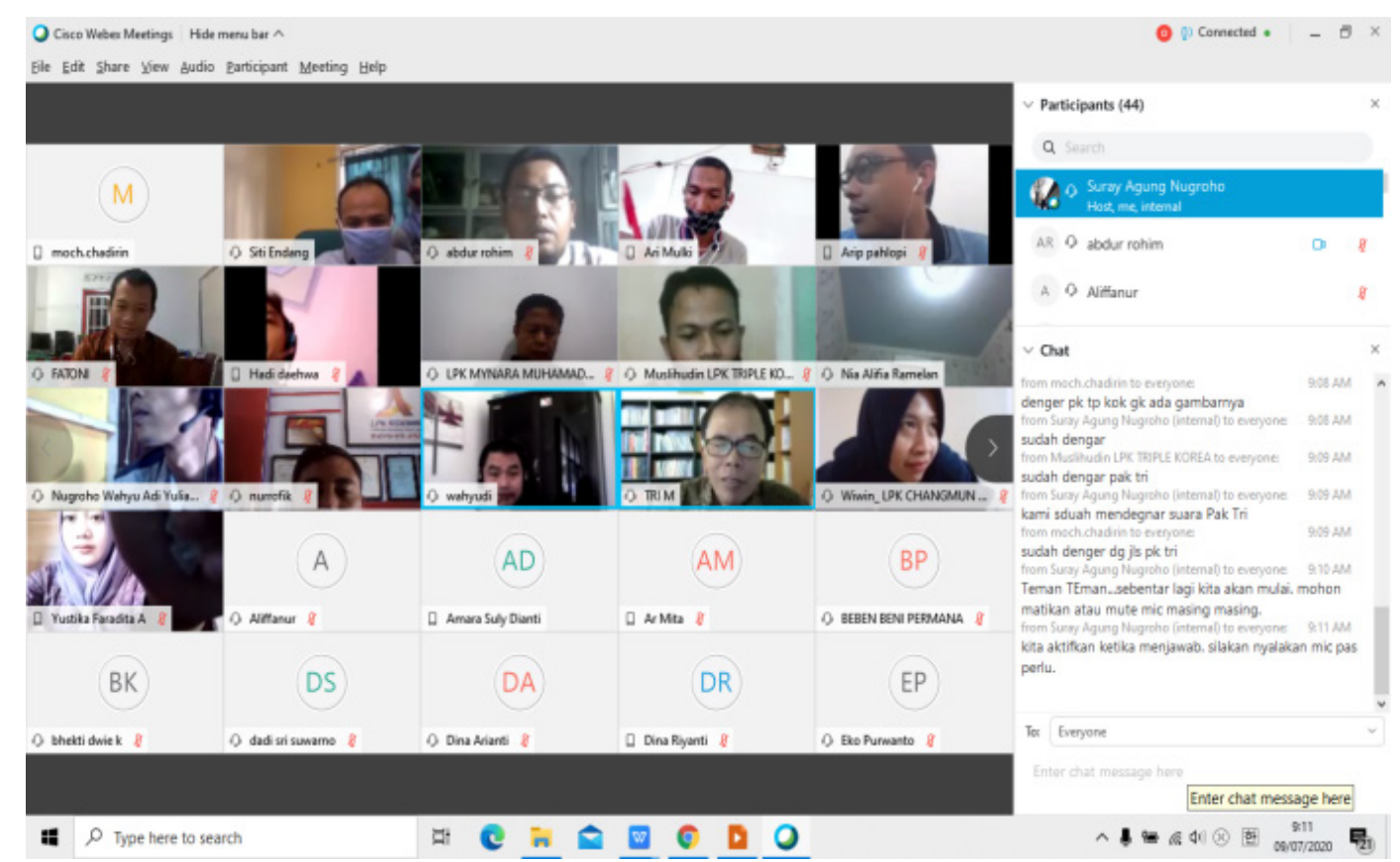

Pic. 3. 1st Day of Community Service (July 9, 2020). (Source: a screenshot from Webex Cisco meeting that we hosted)

meeting even 30 minutes before the program started. As many as 55 participants out of the 90 registered LPK attended the first day.

On the $1^{\text {st }}$ day (July 9), participants took part in a 3-hour session with 3 different topic. During the first topic, they got a chance to learn diverse online platforms available on the internet to support the online classes. As the preliminary survey indicated, not many LPK had had a chance to use platform such as Zoom or Webex. Some LPK never tried one at all and we also learned that for some, even joining an online meeting with more than ten people like what we did via Webex was an experience in itself.

The first topic on first day was geared to introduce all possible platforms that suited each LPK's need. Each platform (Zoom, Webex, Google Meeting, Google Form, Classmarker, etc) was introduced and all participants had a chance to consider which one that would best applicable. On the second topic, they learned practical ways to make online contents on Korean language that would entice students' interest during online learning.We helped them realize the existence of free sites and free tools to create online contents. The last topic on the day was introduction on various methods of conducting online examination. The last topic was deemed important since some participants indicated that learning Korean language was one thing, but having to assess student's performance through online platform was a challenging task. That was the reason as to why this community service also provided them with practical ways to conduct online examination.

The 3-hour session on the first day was deemed not enough by the participants since they wanted more. To anticipate this, we set up a chat-room that all participants could participate to discuss on any topic related with online classes. We had a whole week 


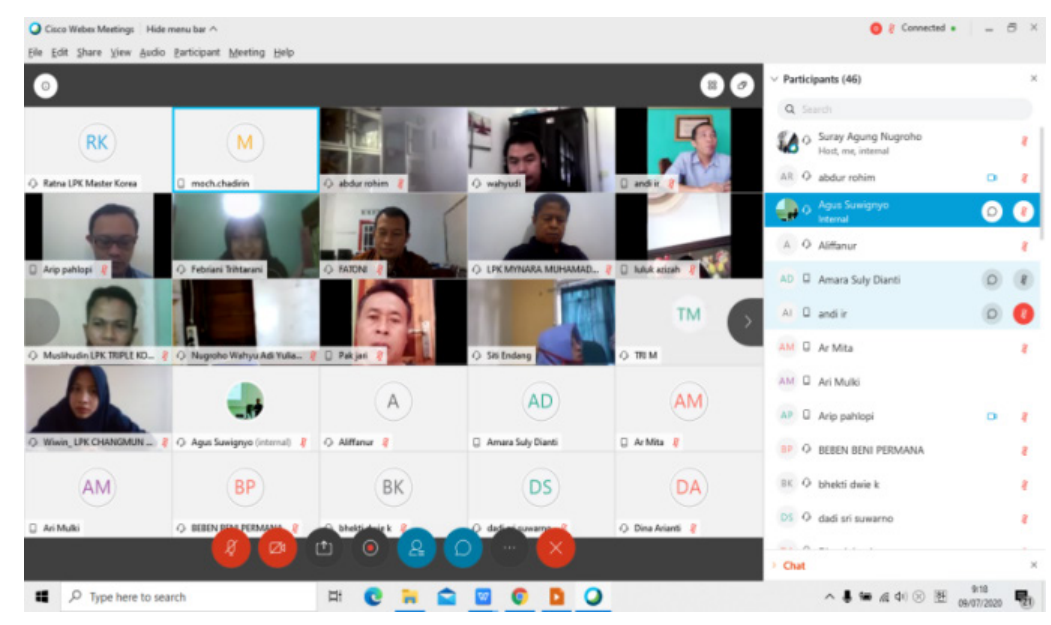

Pic. 4. Participants at the comfort of their own home listening to the presentation on the 1st Day on Community Service. (Source: a screenshot of the $1^{\text {st }}$ day)

prior to the following meeting and we had designed a program to make sure that each participant have a chance to make their first ever online content on Korean language. In other words, as a part of the community service program, we urged all participants to make their own version of Korean language online content. We gave them freedom to express their creativity in the sense that they could make the best use of any platform such as Google Form, Classmarker, Google Classroom, Instagram, YouTube, or any other available platform available. One thing to note was that each content should be made based on the assumption that students would be able to access and understand the content easily. We gave them only 4 days to complete the task before the second meeting on July 16, 2020.

The results started pouring in. It turned out that participants were enthusiastic in making sure that their content to be the best compared to others. Some made short explanatory videos explaining Korean grammars, some others created online tests on Korean language, and some even made an application--something that we did not teach, but as we later found out, they had cooperated with their friends to come up with an idea of creating an app for Korean language classes.

As many as 40 contents were submitted for us to evaluate in a few days prior to the $2^{\text {nd }}$ Community Service on July 16, 2020. Since it would be impossible to assess each of the content, we decided to randomly select the content and have them displayed during the second meeting and ask the related participants to explain about the reasons why they created the content in such a way and to elaborate the content in more details.

Thus, the $2^{\text {nd }}$ day of Community Service was more about discussing the contents that they participants had made a week earlier. It was a rewarding moment for all since they could learn from one another and even they could copy the best practice from other participants. There were some participants who learned about the existence of Google through this community service. They found it rewarding that they learned it through this activity. They were so excited to try making their own version of Korean language quizzes or tests via this platform. This simple fact made it all worthwhile because this was the whole purpose of carrying out such community service in the first place.

This kind of online test (created using Google forms) may seem trivial for those who got used to using online platform. But again, for some of the participants in this 


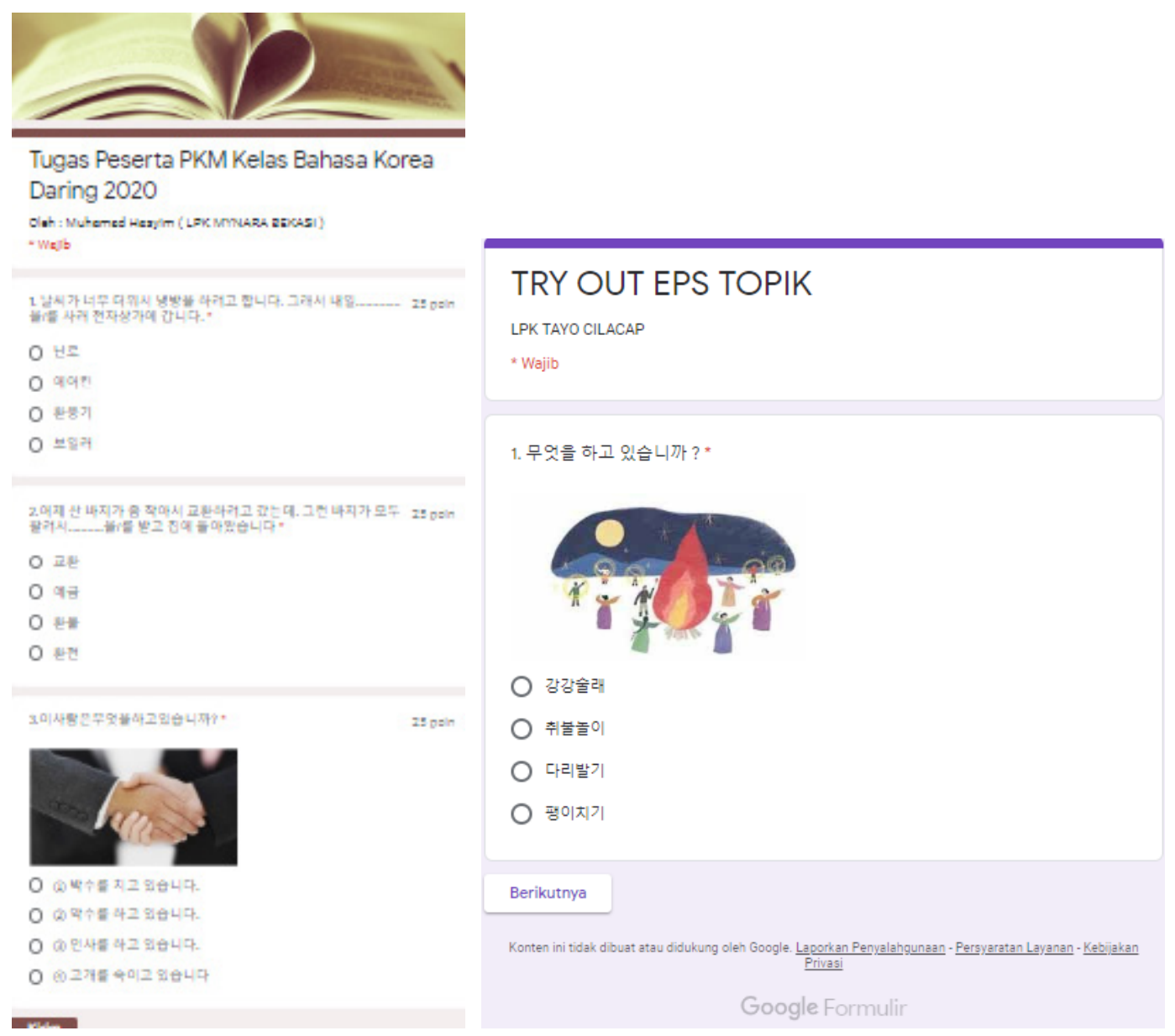

Pic. 5. Examples of simple online tests on Korean Language made by participants. (Source: Screenshot of the Google form)

community service, it was their first time ever on learning about this platform. They found it helpful and interesting that such a platform existed in the first place, not to mention it being free to use. They were so enthusiastic that some even made several versions of the online test. Moreover, they even immediately tested this quizzes to their own students and reported that some students found them enticing.

Another platform that they preferred using was YouTube or any other video-sharing platform with which they conducted online classes. On the second day, we played the video that they made and asked others to comment on them. Due to the limited time of the community service, we selected some participants to present and explain what their videos were about.

We learned that some of them indeed possessed a great amount of creativity. They had their passion in teaching in the first place and on top of that, they poured this into the video as indicated on the editing skills of the video. This video-making was not something that we taught them. They had it all along. It was a rewarding experience to see the videos that they made in a short period of time. More importantly, they were willingly sharing these contents to other participants to see and learn. This is what made the $2^{\text {nd }}$ day of the community service even more lively and engaging. All participants 


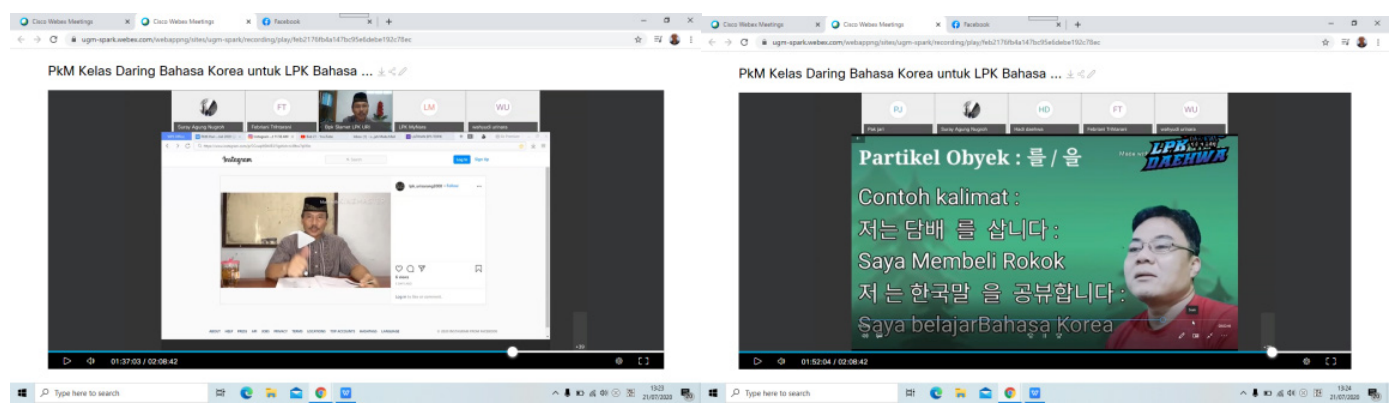

Pic. 6. Videos on Korean Language Teaching made by participants. (Source: screenshot taken during participants' presentation)

could freely get the best practices from others and they learned something out this community outreach.

All in all, along with the participants, out of the 2-day workshop, we managed to achieve three goals. First, we upgraded the knowledge of LPK owners and teachers about various available platforms for conducting online classes that might be necessary and helpful in Korean language teaching. Second, we helped one another in making sure that LPK owners and teachers knew the importance of online classes as a necessary supporting method to offline classes in teaching Korean language. Third, we managed to guide LPK owners and teachers in compiling various Korean-language contents in a simple and easy way that can be used during and post Covid-19 later.

\section{Reflection on Program Achievements}

As a department, we expected and hoped that what we did could be truly beneficial for LPK in winning over and surviving the fight against Covid-19 pandemic. For those who were already and currently running online classes, this community service was regarded as a platform to increase their enthusiasm and confidence that what they were doing was on the right track. For those who had not yet begun online classes, this community service was viewed as a trigger to start conducting or trying the online classes. We also began to see that this community service could be of great help for LPK experiencing financial difficulties because they did not operate at all during the Covid-19 pandemic.

Korean Department could now see that LPK were able to put their dilemmas aside. Through this community service, they saw some applicable practices from other LPK teachers on the methods of conducting online classes. They became confident to continue their role of supporting the availability of skilled human resources to be qualified migrant workers. After participating in this community service, LPK were reported to have created some communication forums to unite and share their ideas and creativity in creating online Korean contents that would secure the continuity of their service in teaching Korean language to the hopeful migrant workers.

Through this community service, we needed to appreciate Pelbakori's role in accommodating the shared vision and goals of many LPK throughout Indonesia. Pelbakori is an important supporting partner in this community service because by directly involving 
Pelbakori through this community service program, Korean Department, Universitas Gadjah Mada has created a synergy between the university as an academic institution under the government and Pelbakori as a private or non-governmental community-based organization outside campus. We both directly have intersected our goals and visions to help the prospective migrant workers in making sure that language learning can be still accessible during the Covid-19 pandemic.

\section{Conclusion}

Community Service Program has been one of the university pillars that we do not take for granted. Despite the seemingly annual activity in its nature, we, the Korean Language and Culture Program, regard this activity as a serious endeavor where we can engage ourselves in finding possible solutions to problems related to the teaching of Korean language as well as the the issue of migration in Indonesia. In relation to the current Covid-19 pandemic, we do hope that what we did could give greater impact in terms of developing LPK's ability and capacity to prepare the online Korean language teaching contents in the middle of and post-Covid-19 pandemic.

\section{References}

https://www.kompas.com/edu/read/2020/06/15/180224171/mendikbud-nadiemmakarim-429-kota-kabupen-di-indonesia-dilarang-membuka https://www.cnbcindonesia.com/news/20200320122952-4-146413/gegara-coronamulai-hari-ini-pengiriman-tki-dihentikan

http://eps.hrdkorea.or.kr 